九州大学学術情報リポジトリ

Kyushu University Institutional Repository

\title{
Land Use in Myanmar with a Case Study in Southern Shan State
}

Egashira, Kazuhiko

Faculty of Agriculture, Kyushu University

Than, Aye Aye

Graduaate School of Bioresource and Bioenvironmental Sciences, Kyushu University

https://doi.org/10.5109/9257

出版情報：九州大学大学院農学研究院紀要. 51 (2)，pp.383-387，2006-10-27. Faculty of Agriculture, Kyushu University

バージョン :

権利関係 : 


\title{
Land Use in Myanmar with a Case Study in Southern Shan State
}

\section{Kazuhiko EGASHIRA* and Aye Aye Than ${ }^{1}$}

\author{
Laboratory of Soil Science, Division of Soil Science and Plant Production, \\ Department of Plant Resources, Faculty of Agriculture, \\ Kyushu University, 812-8581 Fukuoka, Japan \\ (Received June 27, 2006 and accepted July 24, 2006)
}

\begin{abstract}
General aspects of land use in Myanmar were evaluated according to the statistical data issued from FAO. Following it, features of land use in Southern Shan State situated in the eastern hilly region were described as a case study. Ten types of land use were recognized in Southern Shan State. Major land use type was upland field which occupied about 50\% of the cultivated area in Southern Shan State, followed by paddy field. Characteristics of individual land use type were discussed.
\end{abstract}

\section{INTRODUCTION}

Union of Myanmar is a country of Southeast Asia and became a member of ASEAN in 1997, which is now organized by 10 countries. Myanmar spreads from north to south, located between $92^{\circ} 09^{\prime}$ to $101^{\circ} 10^{\prime} \mathrm{E}$ and $9^{\circ} 58^{\prime}$ to $28^{\circ} 31^{\prime} \mathrm{N}$, and has different natural conditions, suggesting different types of land use. Myanmar is an agro-based country. Arable land $\left(95,560 \mathrm{~km}^{2}\right)$ occupied $14.1 \%$ of the national land $\left(676,580 \mathrm{~km}^{2}\right)$ in 1998 and agricultural population (31,776 thousands) did $70.5 \%$ of the total population (45,059 thousands) in 1999 (Egashira, 2002). Crop production is performed mostly under the rain-fed condition with $17 \%$ of irrigation rate of arable-land in 1999/2000 (Kurosawa and Egashira, 2004). Major crops are paddy rice, pulses and edible-oil crops. According to the homepage of the Ministry of Foreign Affairs of Japan (http://www.mofa.go.jp/mofaj/ area/myanmar/index.html (in Japanese)), main exported materials are natural gas and primary products of teak, pulses, rice and shrimp.

Myanmar belongs to the tropical to subtropical monsoon climate. The whole year is separated into following three seasons: hot (middle February to middle May), rainy (middle May to middle October), and dry-cold (middle October to middle February). Annual rainfall remarkably varies with places in the country; the highest rainfall amount was 5,691 mm at Ye of Mon State and the lowest one was $657 \mathrm{~mm}$ at Nyaung Oo of Mandalay Division, as the average of annual rainfall from 1992 to 2001 recorded at the meteorological stations and rainfall stations of the Department of Meteorology and Hydrology. The monsoon rainfall starts in May and lasts to October irrespective of the amount of annual rainfall. But, the amount of monthly rainfall in the rainy season considerably varies from place to place depend-

\footnotetext{
1 Laboratory of Soil Science, Division of Soil Science and Plant Production, Department of Plant Resources, Graduate School of Bioresource and Bioenvironmental Sciences, Kyushu University, Fukuoka 812-8581, Japan

* Corresponding author (E-mail: kegashi@agr.kyushu-u.ac.jp)
}

ing on the annual rainfall.

As stated in the previous paper (Egashira and Aye Aye Than, 2006), we had a short field survey on land use in the highland region of Southern Shan State, or Shan State (south), and in the semi-arid region of Mandalay Division and visited some research farms under the Department of Agricultural Research, Ministry of Agriculture and Irrigation, in late March 2006. In the previous paper (Egashira and Aye Aye Than, 2006), based on the statistical data and on the information obtained by visiting some research farms and through field survey in and around the research farms, we described and discussed cropping characteristics of Myanmar in general and of the highland region of Shan State (south) and the semi-arid region of Mandalay Division as case studies.

In the current report, general aspects of land use in Myanmar were first described and discussed using statistical data. Then land use in the highland region of Southern Shan State was introduced as a case study with information obtained through visit of Land Use Office of Southern Shan State, Myanma Agriculture Service, Ministry of Agriculture and Irrigation.

\section{LAND USE IN MYANMAR}

\section{Land use of the national land}

Tables 1 and 2 show land use of the national land and of the agricultural land, respectively, in Myanmar. The data were quoted from FAO Statistical Databases (http://www.fao.org) and are expressed as three-year averages of 2003 to 2001 and of 1993 to 1991, so that we can minimize the annual variation of data and understand the change occurring during the recent 10 years. As recognized from Table 1, Myanmar has the total area of 67,658 thousands ha of which 65,755 thousands ha is the land area, equivalent to $97.2 \%$ of the total area. Both items did not change between 2003-2001 and 1993-1991. In 1993-1991, the agricultural area occupied $15.4 \%$ while forests and woodland did $47.9 \%$ and all other land did $33.9 \%$ of the total area. It was roughly equivalent to $1 / 6,1 / 2$, and $1 / 3$ of the land area for agricultural area, forests and woodland, and all other land, 
respectively. The agricultural area was 11,052 thousands ha in 2003-2001 and increased by 632 thousands ha from 1993-1991, and occupation in the total area slightly increased from $15.4 \%$ to $16.3 \%$. Items in the FAO agricultural statistics were changed between 1993-1991 and 2003-2001, and non-arable land and non-permanent crops amounted to $81.3 \%$ of the total area in 2003-2001.

\section{Land use of the agricultural land}

As shown in Table 2, around $90 \%$ of the agricultural area is used as arable land in Myanmar. The arable-land area increased by 426 thousands ha from 9,556 thousands ha in 1993-1991 to 9,982 thousands ha in 20032001, but occupation in the agricultural area decreased a little from $91.7 \%$ to $90.3 \%$ during the ten years. The area of permanent crops greatly increased with an increasing rate of 1.499 from 1993-1991 to 2003-2001, although occupation in the agricultural area remains in $6.8 \%$ in 2003-2001. Increase in the area of permanent crops seems to be corresponding to increase in not only fruits cultivation but also rubber and oil palm plantation. The area of permanent pasture in 2003-2001 occupied only $2.8 \%$ of the agricultural area and decreased by more than 10\% from 1993-1991.

Table 3 shows the agricultural and arable-land areas and their ratio of Myanmar and some other countries surrounding or neighboring Myanmar in 2003-2001, which were quoted from FAO Statistical Databases (http://www.fao.org). Myanmar has the higher agricultural and arable-land areas than do the other countries except for Thailand. The ratio of arable-land to agri-

Table 1. Land use of the national land in Myanmar

\begin{tabular}{lccc}
\hline & \multicolumn{2}{c}{ Area (1000 ha) } & \\
\cline { 2 - 3 } Item & $\begin{array}{c}2003-2001 \\
\text { (a) }\end{array}$ & $\begin{array}{c}1993-1991 \\
\text { Ib })\end{array}$ & $\begin{array}{l}\text { Increasing } \\
\text { rate (a/b) }\end{array}$ \\
\hline Total area & 67,658 & 67,658 & 1.000 \\
Land area & $65,755(97.2)^{\mathrm{a}}$ & $65,755(97.2)$ & 1.000 \\
Agricultural area & $11,052(16.3)$ & $10,420(15.4)$ & 1.061 \\
Non-arable land and & $55,016(81.3)$ & - & \\
non-permanent crops & & $32,397(47.9)$ & \\
Forests and woodland & - & $22,938(33.9)$ & \\
All other land & - & & \\
\hline \multicolumn{2}{c}{ Quoted from FAO Statistical Databases: http://www.fao.org. } \\
a Values in the parenthesis are percentage to the total area.
\end{tabular}

cultural areas was highest for Myanmar among the 6 countries and decreased in the order of Bangladesh > Thailand $>$ Viet Nam, Cambodia $>$ Laos. The relatively low ratio of arable-land to agricultural areas is a result of coffee (Laos) and coffee and tea (Viet Nam) cultivation in the hilly and highland regions, and the same thing is applicable to Cambodia.

\section{Area harvested of some crops}

Table 4 shows the area harvested of some crops in Myanmar. The data were quoted from FAO Statistical Databases (http://www.fao.org) and are expressed as three-year averages of 2003 to 2001 and of 1993 to 1991. The area harvested of different crops increased more or less greatly between 1993-1991 and 2003-2001. Total of the area harvested of crops shown in Table 4 was 8,626.0 thousands ha in 1993-1991 and 12,973.4 thousands ha in 2003-2001. This is a combined effect of increase in the area planted, increase in the area harvested itself, and encouragement of cultivation of fallow land, as discussed in the previous paper (Egashira and Aye Aye Than, 2006).

Increase in the arable-land area from 1993-1991 to 2003-2001 was limited to 426 thousands ha. Increase in the area harvested during the same period was 1,666.3 thousands ha for pulses, 1,401.2 thousands ha for paddy rice, and 805.0 thousands ha for edible-oil crops, and they all exceeded increase in the arable-land area. Total increase in the area harvested of crops shown in Table 4 was $4,347.4$ thousands ha and equivalent to 10.2 times of increase in the arable-land area. As a result, the ratio of the area harvested to the arable-land area, designated as the cropping rate, increased from 0.903 in 1993-1991 to 1.300 in 2003-2001. It suggests

Table 3. Agricultural and arable-land areas (1000ha) of Myanmar and some other countries in 2003-2001

\begin{tabular}{lccc}
\hline Country & $\begin{array}{c}\text { Agricultural } \\
\text { area (a) }\end{array}$ & $\begin{array}{c}\text { Arable-land } \\
\text { area (b) }\end{array}$ & $\begin{array}{c}\text { Ratio (b/a) } \\
(\%)\end{array}$ \\
\hline Myanmar & 11,052 & 9,982 & 90.3 \\
Bangladesh & 9,044 & 8,009 & 88.6 \\
Thailand & 19,591 & 15,290 & 78.0 \\
Laos & 1,876 & 917 & 48.9 \\
Cambodia & 5,307 & 3,700 & 69.7 \\
Viet Nam & 9,520 & 6,643 & 69.8 \\
\hline
\end{tabular}

Quoted from FAO Statistical Databases: http://www.fao.org.

Table 2. Land use of the agricultural land in Myanmar

\begin{tabular}{lcccc}
\hline Item & \multicolumn{3}{c}{ Area (1000 ha) } & Increasing \\
\cline { 2 - 4 } & $\begin{array}{c}2003-2001 \\
\text { rate (a) }\end{array}$ & $\begin{array}{c}1993-1991 \\
\text { (b) }\end{array}$ & $\begin{array}{c}\text { Increase } \\
(\mathrm{a}-\mathrm{b})\end{array}$ \\
\hline Agricultural area & 11,052 & 10,420 & 632 & 1.061 \\
Arable land & $9,982(90.3)^{\mathrm{a}}$ & $9,556(91.7)$ & 426 & 1.045 \\
Permanent crops & $757(6.8)$ & $505(4.8)$ & 252 & 1.499 \\
Permanent pasture & $313(2.8)$ & $359(3.4)$ & -46 & 0.872 \\
\hline
\end{tabular}

Quoted from FAO Statistical Databases: http://www.fao.org.

${ }^{a}$ Values in the parenthesis are percentage to the agricultural area. 
that increased intensity of cropping has more strongly contributed to the crop production increase than increase in the arable land during the ten years, leading to shifting from single cropping to double cropping.

\section{LAND USE TYPE AND ITS CHARACTERISTICS IN SOUTHERN SHAN STATE}

\section{Outline of Southern Shan State}

We visited the Land Use Office of Southern Shan State, located in the center of Taunggyi Township, Taunggyi District, Southern Shan State, to get information on the land utilization in Southern Shan State. Shan State is situated in the eastern hilly region of the country and subdivided into Northern, Southern and Eastern. The 10-year average of annual rainfall from 1992 to 2001, recorded at the meteorological stations and rainfall stations of the Department of Meteorology and Hydrology, was in a range of 1,267 to $1,468 \mathrm{~mm}$ at the three stations in Shan State. Southern Shan State has an elevation over around $900 \mathrm{~m}$ and is characterized by the highland agriculture with or without irrigation.

\section{General land use in Southern Shan State}

The latest data on the cultivated area in Southern Shan State, which was obtained in the Land Use Office, is reproduced in Table 5 as a case study on the land use in Southern Shan State. The land use type is divided into ten types. They are paddy field (Le), upland field (Yar), field on the river sediment (Kaing/Kyun), garden, rubber plantation, upland field in the mountainous/hilly area (Taung Yar), mixed farming of paddy field and upland field, of paddy field and garden, and of upland field and field on the river sediment, and others. In general, it is recognized that upland field is a major land use type in Southern Shan State, followed by paddy field. The total cultivated area is 1,168,643 acres, equivalent to $472,938 \mathrm{ha}$, and the total number of farmers is 251,153 with the cultivated area per farmer of 4.65 acres (1.88 ha). The total cultivated area occupies $8.4 \%$ of the total area of $13,857,898$ acres $(5,608,153 \mathrm{ha})$ in Southern Shan State.

Table 4. Area harvested of some crops in Myanmar

\begin{tabular}{lcccc}
\hline & \multicolumn{3}{c}{ Area (1000ha) } & Increasing \\
\cline { 2 - 4 } Crop & $\begin{array}{c}2003-2001 \\
\text { (a) }\end{array}$ & $\begin{array}{c}\text { I993-1991 } \\
\text { rate (a/b) }\end{array}$ & $\begin{array}{c}\text { Increase } \\
\text { (a - b) }\end{array}$ & \\
\hline Rice, Paddy & 6440.5 & 5039.3 & 1401.2 & 1.278 \\
Other cereals & 584.4 & 469.9 & 114.5 & 1.244 \\
Pulses & 2762.8 & 1096.5 & 1666.3 & 2.520 \\
Edible-oil crops & 2368.9 & 1563.9 & 805.0 & 1.515 \\
Industrial crops & 474.3 & 245.0 & 229.3 & 1.936 \\
Kitchen crops & 127.5 & 61.5 & 66.0 & 2.073 \\
Vegetables & 215.0 & 149.9 & 65.1 & 1.434 \\
\hline
\end{tabular}

Quoted from FAO Statistical Databases: http://www.fao.org.

Other cereals: wheat, maize and millets.

Pulses: beans, pigeon peas, chick-peas, cow peas, soybeans and peas.

Edible-oil crops: sesame, groundnuts and sunflower.

Industrial crops: cotton, sugar cane and jute.

Kitchen crops: onions, potatos, garlic, cassava and sweet potatos.

Table 5. Cultivated area in Southern Shan State

\begin{tabular}{|c|c|c|c|c|}
\hline $\begin{array}{l}\text { Type } \\
\text { No }\end{array}$ & Land use type & $\begin{array}{l}\text { Cultivated area } \\
\text { (acre) }\end{array}$ & $\begin{array}{l}\text { Number of } \\
\text { farmers }\end{array}$ & $\begin{array}{l}\text { Cultivated area } \\
\text { per farmer (acre) }\end{array}$ \\
\hline 1 & Paddy field (Le) $)^{\mathrm{a}}$ & $216,385(18.5)^{b}$ & $61,561(24.5)^{\mathrm{b}}$ & 3.51 \\
\hline 2 & Upland field (Yar) & $596,717(51.1)$ & $107,998(43.0)$ & 5.53 \\
\hline 3 & $\begin{array}{l}\text { Field on the river sediment } \\
\text { (Kaing/Kyun) }\end{array}$ & $2,735(0.2)$ & $764(0.3)$ & 3.58 \\
\hline 4 & Garden & $104,725(9.0)$ & $34,028(13.6)$ & 3.08 \\
\hline 5 & Rubber plantation & $225(0.0)$ & $11(0.0)$ & 20.45 \\
\hline 6 & $\begin{array}{l}\text { Upland field in the mountainous/ } \\
\text { hilly area (Taung Yar) }\end{array}$ & $29,929(2.6)$ & $11,290(4.5)$ & 2.65 \\
\hline 7 & Paddy field + Upland field & $132,234(11.3)$ & $21,373(8.5)$ & 6.19 \\
\hline 8 & Paddy field + Garden & $61(0.0)$ & $25(0.0)$ & 2.44 \\
\hline 9 & $\begin{array}{l}\text { Upland field + Field on the } \\
\text { river sediment }\end{array}$ & $9,310(0.8)$ & $2,540(1.0)$ & 3.67 \\
\hline \multirow[t]{2}{*}{10} & Others & $76,322(6.5)$ & $11,563(4.6)$ & 6.60 \\
\hline & Total & $1,168,643$ & 251,153 & 4.65 \\
\hline
\end{tabular}

a Words in the parenthesis are the Burmese terms.

${ }^{\mathrm{b}}$ Values in the parenthesis are percentage to the total cultivated area or total number of farmers. 


\section{Characteristics of individual land use type Paddy field}

Type 1 is paddy field (Le) and occupies $18.5 \%$, a little less than one-fifth, of the total cultivated area. Farmers belonging to type 1 are $24.5 \%$, about onefourth, of the total farmers with 3.51 acres (1.42 ha) of the cultivated area per farmer. The Taryaw Research Farm located in Taunggyi Township, Taunggyi District, covers the lowland agriculture in the highland region of Southern Shan State (Egashira and Aye Aye Than, 2006). Rice is a crop in the paddy field and is mainly cultivated in the rainy season (monsoon paddy) under the rain-fed condition. If irrigation water is available, it is also cultivated in the hot season (summer paddy). In this case dual cropping of paddy rice becomes possible, but it is limited to the paddy field near irrigation sources. Generally in the lowland area of Southern Shan State, summer rice is seeded in March, transplanted in April and harvested in July, and monsoon paddy is transplanted in July and harvested in November. In the cropping pattern of monsoon paddy and following crops, garlic, niger, chickpea, sunflower or tomato is usually cultivated after monsoon paddy. Rice is used for self-consumption in Southern Shan State.

Upland field

Type 2 is upland field (Yar) and occupies 51.1\%, around half, of the total cultivated area. Farmers belonging to type 2 are $43.0 \%$ of the total farmers with 5.53 acres (2.24 ha) of the cultivated area per farmer. The Aung Ban Research Farm located Kalaw Township, Taunggyi District, covers the upland agriculture in the highland region of Southern Shan State (Egashira and Aye Aye Than, 2006). Main upland crops in the highland region of Southern Shan State are upland rice, wheat, maize, sugarcane, garlic, potato, ginger, taro, sweet potato, vegetables, and pulses such as soybean, pigeon pea, butterfly bean and chickpea. Upland crops are cultivated in the cropping pattern, for example, of maize - wheat or maize - chickpea without irrigation. In contrast to rice, upland crops such as maize, garlic, potato, ginger, vegetables and soybean are mainly selling to markets for local and national consumption.

Field on the river sediment

Type 3 is field on the river sediment (Kaing/Kyun). It occupies only $0.2 \%$ of the total cultivated area and is in a limited distribution in Southern Shan State. Farmers belonging to type 3 are $0.3 \%$ of the total farmers with 3.58 acres (1.45 ha) of the cultivated area per farmer. This type of land use is focused on the river sediment deposited in and around/near the river, such as river bed (Kaing) and river bar (Kyun). Crops of potato, garlic, cabbage and cauliflower are cultivated. The land is only seasonally available for cultivation, because it comes up with lowering of water level of the river. The soil is fertile, and crop cultivation is practiced without application of chemical fertilizers. Irrigation is available probably by use of river water.

Garden

Type 4 is garden and occupies $9.0 \%$, about onetenth, of the total cultivated area. Farmers belonging to type 4 are $13.6 \%$ of the total farmers with 3.08 acres (1.25 ha) of the cultivated area per farmer. In this land use, fruits and vegetables are grown in the field around farmers' house. Planted fruits are mainly banana, mango, avocado, jackfruit, peach and strawberry, and cultivated vegetables are usually potato, garlic ginger, cabbage, cauliflower, chyote and cut-flowers.

\section{Rubber plantation}

Type 5 is rubber plantation. The cultivated area as low as 225 acres with 11 farmers, but the cultivated area per farmer is 20.45 acres(8.28 ha) and is prominently highest among the 10 land use types. In Myanmar, rubber as well as cotton, sugarcane, jute, coffee, tea and sericulture are cultivated as industrial crops to promote export earning (Ministry of Agriculture and Irrigation, 2004). However, their cultivation is still limited in Myanmar, as judged from the high ratio of arable-land to agricultural areas (Table 3).

Upland field in the mountainous/hilly area

Type 6 is upland field in the mountainous/hilly area (Taung Yar) and occupies 2.6\% of the total cultivated area. Farmers belonging to type 6 are $4.5 \%$ of the total farmers and the cultivated area per farmer is 2.65 acres (1.07 ha). Type 6 is the former shifting cultivation, and about 1 ha is the maximum area that can be managed by one family in a year in the shifting cultivation (Egashira, 1999, 2003). The most time-consuming work in the shifting cultivation is weeding, and it controls the size of the land for cultivation. Main crops in type 6 are rice, millets, banana, maize, chilly, ginger, sesame, and pulses. Rice is called Taung Yar rice and is not the same as upland rice (Egashira, 2003).

State Manager of Southern Shan State, Myanma Agricultural Service, said to us that shifting cultivation has been converted to permanent farming and that burning occurring on the mountain/hill side is caused accidentally by forest fire and not for shifting cultivation. It is imagined that shifting cultivation has recently been changed to slush and burn with shortening of the fallow period and that slush and burn is then being converted to permanent farming. This conversion may require application of chemical fertilizers and agricultural chemicals to keep crop productivity, as indicated in a case study in North Thailand (Hirai and Hirai, 2004).

\section{Mixed farming}

Types 7 through 9 are mixed farming; type 7 is of paddy field and upland field, type 8 of paddy field and garden, and type 9 of upland field and field on the river sediment. Occupation in the total cultivated area is $11.3,0.0$ and $0.8 \%$ for types 7,8 and 9 , respectively. It is stated that land use of paddy field and/or upland field (types 1,2 and 7) amounts to 945,336 acres (382,568 ha), equivalent to $80.9 \%$ of the total cultivated area. The cultivated area per farmer was varied with types of mixed farming and was 6.19 (2.51 ha), 2.44 (0.99 ha) and 3.67 (1.49 ha) acres for types 7,8 and 9 , respectively. Others

Type 10 is others and occupies $6.5 \%$ of the total cultivated area. The cultivated area per farmer is 6.60 acres (2.67 ha) and is in the second highest level 
among the 10 land use types. A newly introduced cultivation system of apple in the highland region of Southern Shan State, which was observed along the roadside in the filed survey, may belong to this land use type.

\section{ACKNOWLEDGEMENTS}

We express our sincere thanks to Mr. U Kyaw Than, State Manager, and Mr. U Tin Win, Assistant Manager, Land Use Office, of Southern Shan State, Myanma Agricultural Service, for their warm hospitality and nice guidance to our visiting.

\section{REFERENCES}

Egashira, K. 1999 Land use and its impact on environment in Lao P. D. R. Jpn.J. Soil Sci. Plant Nutr., 70: 335-340 (in Japanese)

Egashira, K. 2002 Statistics on agricultural population, land use, and production of cereals in southeastern and southern Asian countries. Sci. Bull Fac. Agric., Kyushu Univ., 57: 99-108 (in Japanese)

Egashira, K. 2003 Field survey in Myanmar -invitation to Asia-. Sci. Bull Fac. Agric., Kyushu Univ., 57: 177-211 (in Japanese)

Egashira, K. and Aye Aye Than 2006 Cropping characteristics in Myanmar with some case studies in Shan State and Mandalay Division. J. Fac. Agric., Kyushu Univ., 51: 373-382

Hirai, H. and M. Hirai 2004 Having a view of "sustainable development" at slush and burn villages. In "Taking off in Agriculture of Southeast Asia", ed. by K. Natsuaki and K. Itagaki, Norin Tokei Kyoukai, Tokyo, pp.69-101 (in Japanese)

Kurosawa, K. and K. Egashira 2004 Comparison and future prediction on agricultural indexes in countries of Southeast Asia -characterization of agriculture in terms of annual changes in the arable-land area, consumption of nitrogen fertilizer and production of principal crops during the past 25 years-. Jps. J. Soil Sci. Plant Nutr., 75: 125-133 (in Japanese)

Ministry of Agriculture and Irrigation 2004 Myanmar Agriculture in Brief. Yangon (Myanmar), 39 pp. 